doi $10.15826 /$ recon.2020.6.3.019

JEL I38

\title{
Challenges of small- and medium-sized businesses in Pakistan due to COVID-19 pandemic
}

\author{
Ya. Shah ${ }^{1} \bowtie$, Yu. Liu ${ }^{1}$, Faiza Shah ${ }^{1}$, Fadia Shah ${ }^{2}$ \\ ${ }^{1}$ School of Business, Zhengzhou University, Zhengzhou, China; yasirshah_pk@yahoo.com \\ ${ }^{2}$ Shaheed Zulfiqar Ali Bhutto Institute of Science and Technology, Islamabad, Pakistan
}

\begin{abstract}
Relevance. Human health is essential to economic activity and social development. The rapid spread of the coronavirus disease (COVID-19) all around the world can be particularly disastrous for low-income persons, which means that the pandemic poses a severe threat for developing countries. In Pakistan, small and medium enterprises (SMEs) were hit especially hard by the pandemic and lockdown restrictions. This research focuses on the economic challenges faced by Pakistan in combatting the impacts of the pandemic. Research objective. The purpose of the article is to identify the difficulties faced by SMEs as a result of the coronavirus infection. Data and methods. The methodological approach presents an analysis of statistical data to show the main problems of the SME sector during the COVID-19 pandemic. The study used the data from the statistical report of the Ministry of Health of the Government of Pakistan (GOP), as well as the data from previous studies on the effects of COVID-19 pandemic. Results. The study identified problems for SMEs during COVID-19, such as the lack of capital and the lack of satisfactory business plans. Moreover, poverty is one of the most serious problems in Pakistan, which is why SMEs cannot afford prolonged isolation during the Covid-19 pandemic and individual entrepreneurs have to risk their lives for their families. The government of Pakistan has adapted steps to control the epidemic, however, so far there is no policy for small business investors. The authorities are still working on the policies for small business units. Conclusions. Although Pakistan has adopted many protective measures, the situation regarding measures to support SMEs still leaves much to be desired. The lack of state support contributes to the general economic crisis the country has faced due to the pandemic.
\end{abstract}

\section{KEYWORDS}

COVID-19, SMEs, economic challenges, poverty, Pakistan

\section{FOR CITATION}

Shah, Ya., Liu, Yu., Shah, Faiza, \& Shah, Fadia (2020) Challenges of small- and medium-sized businesses in Pakistan due to COVID-19 pandemic.

R-economy, 6(3), 222-226. doi: 10.15826/recon.2020.6.3.019

\section{Вызовы перед малыми и средними предприятиями Пакистана, вызванные пандемией COVID-19}

\author{
Я. Шах ${ }^{1}$ Ю. Лиу ${ }^{1}$, Фаиза Шах ${ }^{1}$, Фадиа Шах ${ }^{2}$ \\ ${ }^{1}$ Школа бизнеса, Университет Чжэнчжоу, Чжэнчжоу, Китай \\ ${ }^{2}$ Институт науки и технологий Шахида Зульфикара Али Бхутто, Исламабад, Пакистан
}

\section{АННОТАЦИЯ}

Актуальность. Здоровье населения крайне важно для экономической активности и социального развития. Быстрое развитие коронавирусной инфекции по всему миру может быть болезненной для малоимущего населения, что означает, что пандемия представляет серьезную угрозу для развивающихся стран. В Пакистане малые и средние предприятия особенно пострадали из-за пандемии и ограничений. Это исследование фокусируется на экономических вызовах, встреченных Пакистаном в борьбе с последствиями пандемии. Цель исследования. Исследование нацелено на идентификацию сложностей, встреченных малыми и средними предприятиями в результате эпидемии коронавируса. Данные и методы. Методологический подход заключается в анализе статистических данных с целью демонстрации основных проблем малого и среднего бизнеса во время пандемии. Исследование использует данные статистических отчетов Министерства здравоохранения Пакистана, а также данные уже существующих научных работ про эффекты пандемии. Результаты. Исследование обнаружило проблемы малых и средних предприятий во время пандемии коронавируса, такие как недостаток капитала и несовер(c) Shah, Ya., Liu, Yu., Shah, Faiza, Shah, Fadia, 2020
\end{abstract}

\section{КЛЮЧЕВЫЕ СЛОВА}

COVID-19, малые и средние предприятия, экономические вызовы, бедность, Пакистан 
шенство бизнес-планов. Более того, бедность - одна из самых серьезных проблем в Пакистане, и она стала причиной того, что малые и средние предприятия не могли позволить себе длительный период запрета на работу и их работники должны были рисковать своими жизнями, чтобы обеспечить свое существование. Правительство Пакистана предпринимало попытки контроля эпидемии, однако не предпринимало никаких шагов по поддержке малого бизнеса. Власти страны до сих пор работают над разработкой соответствующей политики. Заключение. Хотя Пакистан и предпринял ряд мер по защите населения, ситуация касательно поддержки малых и средних предприятий гораздо хуже желаемой. Слабая их поддержка государством стала частью общего экономического кризиса страны, вызванного пандемией.

\section{ДЛЯ ЦИТИРОВАНИЯ}

Shah, Ya., Liu, Yu., Shah, Faiza, \& Shah, Fadia (2020) Challenges of small- and medium-sized businesses in Pakistan due to COVID-19 pandemic. R-economy, 6(3), 222-226. doi: 10.15826/recon.2020.6.3.019

\section{Introduction}

The COVID-19 pandemic has posed a major challenge to the whole world (Toda, 2020). The World Health Organization (WHO) declared the COVID-19 outbreak as the Sixth Public Health of Emergency Services (SPHEC) on January 30, 2020 (Waris et al., 2020). Rana et al. (2020) explain that the countries bordering China were affected the most, including Pakistan. By June 2020, the number of cases in the country has been increasing fast and the situation is getting worse day by day.

In addition to its serious impact on public health, COVID-19 has had an impact on the economy, and especially on SMEs, which have fewer resources to keep their businesses running. The result is massive staff layoffs and closures. According to the results of a sociological study by Bartik et al. (2020), 43\% of SMEs in the United States are temporarily closed, and between January and April 2020 there was a 40\% reduction in the number of employees.

Pakistan as a developing country is already facing many challenges including poverty, shortage of electricity, business loss, food insecurity, and many other natural and manmade disasters (Cui, 2011; Wit, 2014) in our view, the so-called dynamic classification method should be favored when determining the contribution of small businesses towards job creation. First, it is the only method that consistently attributes job creation or loss to the size class in which it actually occurs. In addition, dynamic classification has two other advantages: (i. The average of $24 \%$ total population of the country are living below the poverty line $(\mathrm{Ba}-$ luchistan, 2019). The lockdown due to COVID-19 has hit the economy of Pakistan hard and now a large number of people may face the danger of starvation. The crisis in particular affected small and medium-sized businesses (SMEs), which are already performing below the capital structuring (Kabir et al., 2020).
The aim of this article is to describe the current situation in Pakistan due to COVID-19 with a focus on SMEs, which are most affected by the crisis. The authors formulate key challenges for the development of SMEs in the pandemic and characterize the social consequences of the economic crisis. It is emphasized that the specifics of the current crisis are largely related to the long-standing socio-economic problems of Pakistan as a developing country.

\section{COVID-19 and the current situation in Pakistan}

Pakistan is a developing country having lots of other financial crisis in the country. Mostly the small investors are affected because they earn daily for their survival. These small industries are worse affected and people are even starving to death due to COVID-19.

Shafi et al. (2020) collected and analyzed online survey data from 184 Pakistani SMEs, which showed that most businesses were severely affected by COVID-related restrictive measures. Among the problems faced by SMEs there are financial problems, supply chain disruption, decreased demand, reduced sales and profits. In addition, more than $83 \%$ of businesses had no plans to address the economic problems caused by the pandemic. Given the alarming epidemiological situation, we assume that the economic situation of SMEs is permanently deteriorating.

Table 1 shows the number of confirmed COVID cases in different provinces of Pakistan, according to the report of the Ministry of Health of the Government of Pakistan (GOP) as of $14^{\text {th }}$ June 2020. As the table illustrates, most cases and deaths from COVID-19 were concentrated in provinces Punjab and Sindh.

From this date to onwards, the number of confirmed cases in Pakistan has been growing. Effective measures taken by the government of $\mathrm{Pa}$ - 
kistan, however, helped to contain the pandemic. Compared with other developing countries, Pakistan has shown less cases because the government has actively participated in the control of the pandemic from the start. Yet another challenge was that the country simply could not afford to close down all its business sectors for a long time.

Table 1

Number of cases and deaths from COVID-19

in Pakistan, by province (as of 14 June 2020)

\begin{tabular}{|l|c|c|c|}
\hline \multicolumn{1}{|c|}{ Provinces } & $\begin{array}{c}\text { Confirmed } \\
\text { Cases }\end{array}$ & Death & $\begin{array}{c}\text { Active } \\
\text { Cases }\end{array}$ \\
\hline Punjab & 52601 & 969 & 51632 \\
\hline Sindh & 53805 & 831 & 52974 \\
\hline Khyber Pakhtunkhwa & 18013 & 675 & 17338 \\
\hline Balochistan & 8177 & 85 & 8092 \\
\hline Gilgit Baltistan & 1129 & 16 & 1113 \\
\hline Federal & 7934 & 75 & 7859 \\
\hline Azad Jammu \& Kashmir & 604 & 12 & 592 \\
\hline Total & 142263 & 2663 & 139600 \\
\hline
\end{tabular}

Source: the authors' calculations are based on Statistical Data. Pakistan: COVID-19 - Situation Report (As of 14 June 2020). https://reliefweb.int/report/pakistan/pakistan-covid-19-situation-report-14-june-2020.

\section{Key challenges faced by SMEs in Pakistan}

Qiu et al. (2020) explains that business expansion, including SME activities, is associated with the risk of increased incidence of COVID-19. Moreover, the growth in trade can significantly increase the spread of infectious diseases, for example, influenza (Adda, 2016). Shah et al. (2018) contend that most SMEs are unable to meet their financial needs, which is an alarming sign because SMEs are a key to economic growth, innovation, revenue generation, and employment for day to day workers (Nooteboom, 1994; Verhees and Meulenberg, 2004; Beck and Demirguc-Kunt, 2006) in many sectors of a developing economy, such as manufacturing, services and trade (Ahmed et al, 2014).

A common problem many SMEs face is the lack of capital. During the COVID-19 pandemic, SMEs in Pakistan encountered a number of financial and institutional challenges in addition to those they already had to deal with (Baker et al., 2020a.), such as the lack of innovative products, high investment in government securities, high transactional costs, lack of satisfactory business plans, accounting, and other information, insufficient assets for use as security, lack of financial awareness, limited new or innovative approaches to addressing clients, political instability, energy crisis, lack of infrastructure, rising unemployment and the lack of new technologies.

The problem of poverty is one of the most serious problems in Pakistan as many people have a low income and during the COVID-19 pandemic could not afford a long lockdown and risks their own life for the sake of their families. In Pakistan, it is quite typical that one person provides for the whole family, which is why he or she often cannot afford to close down the business for even a single day. Therefore, these small business owners are facing the biggest threat due to COVID-19. In addition to the measures taken by the government to contain the pandemic, such as opening special hospitals, laboratories, quarantine facilities or an awareness raising campaign and lockdown measures, health checks of passengers coming from abroad, it is essential that measures should be taken to support SMEs.

The government's decision to lift some of the lockdown restrictions was determined by the need to support low-income people and small businesses. SMEs were, however, required to follow certain procedures, for example, ensuring that clients wore masks and gloves, using sanitizers at offices and maintaining a distance of 6 feet (1.8 meters) from other people etc. Moreover, the government has not yet found ways to provide tangible support for SMEs.

The economic recession is defined by the reductions within an economic cycle, which reduces economic efficiency and is measured by gross domestic product (GDP) and the unemployment rate of any country. Any changes in the economic cycles lead to a change in the GDP and unemployment rate (Javed, 2000). Carbó-Valverde et al. (2016) assures destruction leads to lower GDP and increases the unemployment rate in the country and vice versa. The loss of jobs and a rise in unemployment have a significant effect on people's mental state and some studies indicate the positive association between recession and suicide rates (Info 2020; Rana et al. 2020; Baker et al. 2020b).

\section{Conclusions}

Like other developing countries, Pakistan has been struggling with the consequences of the COVID-19 pandemic and the lockdown measures, in particular SMEs have proven to be most vulnerable to the economic effects of the latter. Small-scale entrepreneurs work on daily basis to meet their daily needs. The government of Paki- 
stan should implement procedures and rules and, most importantly, financial support for SMEs.

In fact, the pandemic aggravated such problems of SMEs as the lack of capital and the lack of satisfactory business plans. Moreover, since poverty is one of the most serious problems in Pakistan, most SMEs simply cannot afford prolonged isolation during the Covid-19 pandemic.

\section{References}

Toda, A.A. (2020). Susceptible-Infected-Recovered (SIR) Dynamics of COVID-19 and Economic Impact. 1-15.

Waris, A., Khan, A.U., \& Ali, M. (2020). COVID-19 outbreak: Current Scenario of Pakistan. New Microbes and New Infections, 35, 100681. doi: 10.1016/j.nmni.2020.100681

Rana, W., Mukhtar, S., \& Mukhtar, S. (2020). Mental health of medical workers in Pakistan during the pandemic COVID-19 outbreak. Asian Journal of Psychiatry, 51:102080. doi: 10.1016/j. ajp.2020.102080

Bartik, A., Bertrand, M., Cullen, Z., Glaeser, E., Luca, M., \& Stanton, C.(2020)How Are Small Businesses Adjusting to COVID-19? Early Evidence From a Survey. Harvard business school. Retrieved from: https://hbswk.hbs.edu/item/how-are-small-businesses-adjusting-to-covid-19-early-evidencefrom-a-survey

Cui, J., Hu, H., \& Zhang, D. (2011). Small and Medium-sized Enterprise Trade Credit Distribution Study,2011 International Conference on Information Management, Innovation Management and Industrial Engineering, Shenzhen, 316-319. doi: 10.1109/ICIII.2011.358

Wit, G., \& de Kok, J. (2014). Do small businesses create more jobs? New evidence for Europe. Small Business Economics, 42, 283-295. doi: 10.1007/s11187-013-9480-1

Baluchistan Drought Needs Assessment (BDNA) Report (2019). Retrieved from: https://reliefweb. int/report/pakistan/balochistan-drought-needs-assessment-bdna-report-february-2019\#: :tex$\mathrm{t}=\mathrm{As} \% 20$ per\%20the\%20latest\%20poverty,and\%209.4\%25\%20in\%20urban\%20areas

Kabir, M., Afzal, M.S., Khan, A., \& Ahmed, H. (2020). COVID-19 pandemic and economic cost; impact on forcibly displaced people. Travel Medicine and Infectious Disease, 35, 101661. doi: 10.1016/j.tmaid.2020.101661

Shafi, M., Liu, J., \& Ren, W.(2020) Impact of COVID-19 pandemic on micro, small, and medium-sized Enterprises operating in Pakistan. Research in Globalization. 100018. doi: 10.1016/j.resglo.2020.100018

Qiu, Y., Chen, X., \& Shi, W. (2020). Impacts of social and economic factors on the transmission of coronavirus disease 2019 (COVID-19) in China. Journal of Population Economics, 33, 1127-1172, doi: $10.1007 / \mathrm{s} 00148-020-00778-2$

Adda, J. (2016) Economic activity and the spread of viral diseases: Evidence from high frequencydata, Quarterly Journal of Economics, 891-941.

Shah, F., Liu, Y., Ahmed, J., Shah, Y., \& Shah, F. (2018). Impact of Risk on Use of Trade Credit : Empirical Evidence from Non-financial Firms in Pakistan. Sukkur IBA Journal of Economics and Finance, 2(1), 55-67.

Nooteboom, B. (1994). Innovation and diffusion in small firms: Theory and evidence. Small Business Economics, 6, 327-347. doi: 10.1007/BF01065137

Verhees, F.J.H.M., \& Meulenberg, M.T.G. (2004). Market Orientation, Innovativeness, Product Innovation, and Performance in Small Firms, Journal of Small Business Management, 42, 134-154. doi: $10.1111 /$ j.1540-627X.2004.00102.X

Beck, T., \& Demirguc-Kunt, A. (2006). Small and medium-size enterprises: Access to finance as a growth constraint. Journal of Banking and Finance, 30, 2931-2943. doi: 10.1016/j.jbankfin.2006.05.009

Ahmed, J. (2014) Determinants of Trade Credit: The Case of a Developing Economy. Europian Research, 83(9-2), 1694-1706. doi: 10.13187/er.2014

Baker, S., Bloom, N., Davis, S., \& Terry, S. (2020a). COVID-Induced Economic Uncertainty. National Bureau of Economic Research, Cambridge, 15, doi: 10.3386/w26983 
Javed, A. (2020).(Rep.) Policy Review Economic Impact of Coronavirus and Revival Measures: Way Forward for Pakistan.

Carbó-Valverde S, Rodríguez-Fernández F, Udell GF (2016). Trade Credit, the Financial Crisis, and SME Access to Finance. Journal of Money, Credit and Banking, 48, 113-143. doi: 10.1111/ jmcb.12292

Baker, S., Meyer, S., Pagel, M., \& Yannelis, C. (2020b). How Does Household Spending Respond to an Epidemic? Consumption During the 2020 COVID-19 Pandemic. The Review of Asset Pricing Studies, raaa009, 37, doi: 10.1093/rapstu/raaa009

\section{Information about the authors}

Yasir Shah - PhD Scholar, School of Business, Zhengzhou University (100 Science Avenue, Zhengzhou, Henan, 450001, P. R. China); e-mail: yasirshah_pk@yahoo.com

Yumin Liu - Associate Professor, School of Business, Zhengzhou University (100 Science Avenue, Zhengzhou, Henan, 450001, P. R. China); e-mail: zzyuminliu@126.com

Faiza Shah - PhD Scholar, School of Business, Zhengzhou University (100 Science Avenue, Zhengzhou, Henan, 450001, P. R. China); e-mail: faizashah55@gmail.com

Fadia Shah - Assistant Professor, Shaheed Zulfiqar Ali Bhutto Institute of Science and Techno$\log$ (Street \# 09, Plot \# 67, Sector H-8/4, Islamabad, Pakistan); e-mail: fadiashah13@yahoo.com

ARTICLE INFO: received June 7, 2020; accepted September 1, 2020

\section{Информация об авторах}

Шах Ясир - PhD-кандидат, Школа бизнеса, Университет Чжэнчжоу (100 Сайенс Авеню, Чжэнчжоу, Хэнань, 450001, Китай); e-mail: yasirshah_pk@yahoo.com

Лиу Юмин - доцент, Школа бизнеса, Университет Чжэнчжоу (100 Сайенс Авеню, Чжэнчжоу, Хэнань, 450001, Китай); e-mail: zzyuminliu@126.com

Шах Фаиза - PhD-кандидат, Школа бизнеса, Университет Чжэнчжоу (100 Сайенс Авеню, Чжэнчжоу, Хэнань, 450001, Китай); e-mail: faizashah55@gmail.com

Шах Фадиа - доцент, Институт науки и технологий Шахида Зульфикара Али Бхутто (Стрит \# 09, Плот \# 67, Сектор Н-8/4, Исламабад, Пакистан); e-mail: fadiashah13@yahoo.com

ИНФОРМАЦИЯ О СТАТЬЕ: дата поступления 7 июня 2020 г.; дата принятия к печати 1 сентября 2020 г. 